Earlier records of this gull in Saskatchewan were of three seen on June 9, 1914, on Sandy Lake, Churchill River (Buchanan, 1920:224), and 11 found on June 11, 1960 resting on open water at the mouth of Black Bay, Lake Athabasca (Nero, 1963: 25), two specimens of which were taken. Taverner and Sutton (1934:25) considered it a rare transient at Churchill on the Arctic coast of Manitoba. Although not noted in 1930, four specimens (three females and one male) were taken in June 1931 within six miles of Churchill and adult specimens were taken in June 1933. Soper observed a single gull of this species in winter plumage on October 4, 1945 at Lake Audy in Riding Mountain National Park (1953:25) in Mani- toba. Lake Audy is approximately 85 miles southeast of Madge Lake. These lakes are similarly situated, being located on relatively small boreal escarpments in the southern sections of the respective provinces.

\section{LITERATURE CITED}

Buchanan, A. 1920. Wild life in Canada. McClelland, Goodchild and Stewart, Ltd. Toronto. $264 \mathrm{pp}$.

Godfrey, W. E. 1966. The birds of Canada. Nat. Mus. Can. Bull. 203.

Nero, R. W. 1963. Birds of the Lake Athabasca region, Saskatchewan Special Pub. No. 5, Nat. Hist. Soc., Regina.

Peterson, R. T. 1947. A field guide to the birds. Houghton Mifflin Co., Boston.

Soper, J. D. 1953. The birds of Riding Mountain National Park, Manitoba, Canada. Can. Wildl. Serv., Wildl. Mgt. Bull. No. 6, Series 2. Mimeo.

Taverner, P. A., and G. M. Sutton. 1934. The birds of Churchill, Manitoba. Annals Carnegie Mus., Vol. 23, pp. 1-83.

\title{
FURTHER COMMENTS ON PRAIRIE RECORDS OF THE KNOT
}

\section{by Martin K. McNicholl, Zoology Department, University of Manitoba, Winnipeg}

In a recent paper (McNicholl, 1969 a), I attempted to gather together records of the Knot (Calidris camutus) in the prairie provinces of Canada. Published additional records are now available for West Shoal Lake, Manitoba (McNicholl, 1969 b), Cold Lake, Alberta (Blokpoel, 1969), and Frank Lake and Calgary, Alberta (Smith and Wershler, 1969). In addition, I have recently been informed that a specimen collected by Sam Waller at The Pas on May 26, 1947 is in Mr. Waller's scientific collection in The Little Northern Museum (pers. corres. June and July, 1969). Also, "seven or eight" were seen at the University of Manitoba Field Station at Delta at about 9:00 a.m. on May 22, 1969 by Harold R. Bauer. Two were still present at 12:45 p.m. when the writer and Dr. Roger M. Evans visited the site with Bauer.

In my discussion on the migration routes of the Knot across the prairies, I proposed a regular flight through the western and central portions of the Alberta prairies in addition to the flight east of Manitoba proposed by Cooke (1910). Blokpoel (op. cit.) does not feel that this idea of a division of the interior flight-path into two flights can be supported. He feels that his record of a single Knot at Cold Lake, June 16, 1968, refutes the proposal because it "helps to fill" the "considerable gap in locations [of Knots] on the prairie" which I had proposed. However, it should be noted that, as Blokpoel states, Cold Lake is not in the prairies, but "within the Boreal Forest." Blokpoel suggests that the Alberta flight does not proceed over the southwestern and southcentral Alberta prairie, but rather over the eastern part of the province, because the map in Salt and Wilk (1966) clearly charts the migration of the Knot over the eastern part of the province. However, it must be pointed out that the map in Salt and Wilk is a summary map, based on the sites shown in Figure 2, p. 32 of my paper (196 a). These locations are clearly 
in the south-central portion of the province, near the western limits of the prairies. Furthermore, Salt and Wilk (op. cit.) state "it [the Knot] apparently passes over the southern prairies without stopping" because of the scarcity of records there. Blokpoel feels that the lack of records for southwestern Saskatchewan can be explained by the relative lack of reporting bird-watchers in that area. I agree that this could explain the total lack of records there, but if the Knot regularly used the area in even small numbers, one would expect that at least a few records would be available from the capable observers that are and have been in the area. The proposed additional western flight is based on numbers and regularity, not on actual locations of a few scattered records. If the Knot was a regular migrant across the prairie in any abundance, one would expect more records from such heavily observed areas as Moose Jaw, Regina, Delta, and Winnipeg. Moreover, although Knots have een "observed in the area around Saskatoon for several successive years" as Blokpoel (op. cit.) states, these have been in small numbers (see table 2, p. 31, McNicholl, 1969a). On this basis I must still follow the hypothesis that the interior North American flight of the Knot follows two main pathways around the prairies, i.e., one through southcentral Alberta, the other east of Manitoba. The scattered observations in Saskatchewan and Manitoba appear to represent strays from the main route.

Blokpoel (op. cit.) attributes the lack of fall observations in Saskatchewan to their less conspicuous coloring and smaller flocks (at least, in part). However, it should be pointed out that the most importat distinguishing features of the Knot are not plumage characteristics, but the chunky body and short bill (see Peterson, 1947, or any other bird guide), and that the Knot is less difficult to distinguish in the fall than are many other small shorebirds, many of which are regularly identified. At noted in my paper, most authorities indicate that the fall migration is farther east than thte spring migration, and I do not feel that there is any evidence to refute that view, except to point out their regularity in fall through Alberta. Even there the flights are thought to be smaller in the fall (Salt and Wilk, op. cit.).

Finally, I must join with Blokpoel in re-emphasizing the need for more information in determining the Knot's migration route in detail. This is not only true of the prairie region, where we have enough records to at least provide discussion, but even more true of the boreal forest areas, where we have very few records. Blokpoel's record at Cold Lake, Waller's record at The Pas, the Lake Athabasca records (Nero, 1963; McNicholl, $1969 \mathrm{a})$, and the Lake St. Martin record (Shortt and Waller, 1937) should help to fill in this gap in our knowledge, but at the moment may open up more questions than they answer. For example, as Waller (pers. corres., July 15, 1969) has pointed out, the June 13, 1935 date for the Lake St. Martin record seems very late for spring migration. On the other hand, it is early for fall migration. Perhaps it was a non-breeding bird. I would urge readers with other records of the Knot in the prairie provinces either to publish them or send them to the writer.

\section{LITERATURE CITED}

Ilokpoel, H. 1969. A Knot recorl for the Alberta - Saskatchewan border. Blue Jay, $27: 83$.

Cooke, W. W. 1910. Distribution and migration of North American shorebirds. U.S. Dept. Agr. Biol. Surv. Bull. No. 35. 100 pp.

McNicholl M. K. 1969a. The Knot as a migrant in southern Manitoba. Blue Jay, $27: 28-35$.

McNicholl, M. K. 1969b. Further note on Knot records for Manitoba. Blue Jay, $27: 83$.

Nero, R. W. 1963. Birds of the Lake Athabasca region, Saskatchewan. Spec. Publ. No. 5. Sask. Nat. Hist. Soc., Regina. 143 pp.

Peterson, R. T. 1947. A field guide to the birds (second revised ed.). Houghton Mifflin Co., Boston. $290 \mathrm{pp}$.

Salt, W. R. and A. L. Wilk. 1966. The birds of of Alberta. Second (revised) ed. Dept. of industry and development. Govt. of Alta. $511 \mathrm{pp}$.

Shortt, T. M., and S. Waller. 1937. The birds of the Lake St. Martin region, Manitoba. Contr. Roy. Ont. Mus. Zool., No. 10. 51 pp.

Smith, W. W., ad C. R. Wershler. 1969. Some 1968 southern Alberta bird observations. Blue Jay, $27: 88-92$. 